\title{
The Peddlers' Aristocracy: Social Closure, Path-Dependence, and Street Vendors in São Paulo
}

\section{Jacinto Cuvi}

\section{Qualitative Sociology}

ISSN 0162-0436

Qual Sociol

DOI 10.1007/s11133-018-9404-0
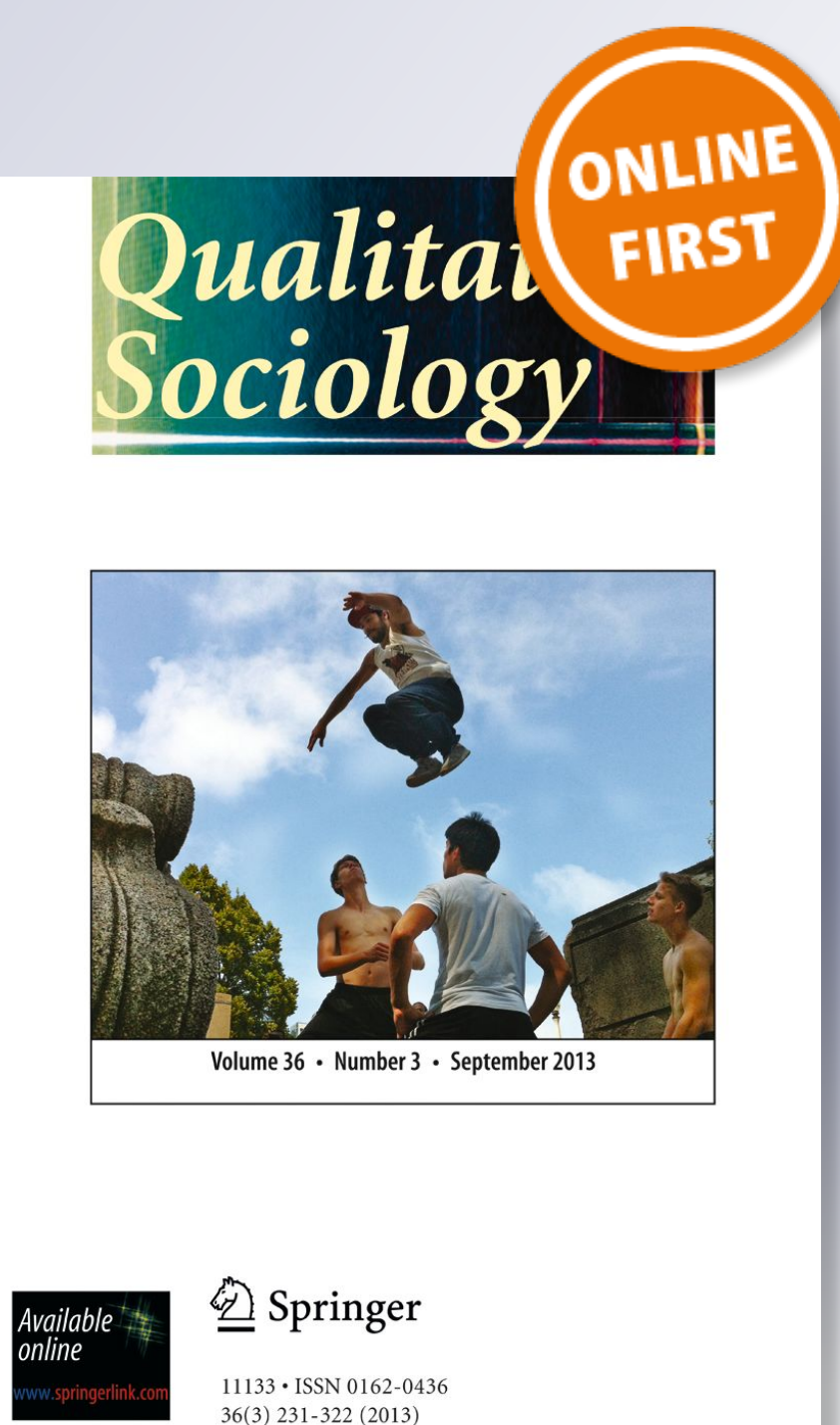

算 Springer

$11133 \cdot$ ISSN 0162-0436

36(3) 231-322 (2013) 
Your article is protected by copyright and all rights are held exclusively by Springer Science+Business Media, LLC, part of Springer Nature. This e-offprint is for personal use only and shall not be self-archived in electronic repositories. If you wish to selfarchive your article, please use the accepted manuscript version for posting on your own website. You may further deposit the accepted manuscript version in any repository, provided it is only made publicly available 12 months after official publication or later and provided acknowledgement is given to the original source of publication and a link is inserted to the published article on Springer's website. The link must be accompanied by the following text: "The final publication is available at link.springer.com". 


\title{
The Peddlers' Aristocracy: Social Closure, Path-Dependence, and Street Vendors in São Paulo
}

\author{
Jacinto Cuvi ${ }^{1}$
}

Published online: 28 December 2018

(C) Springer Science+Business Media, LLC, part of Springer Nature 2018

\begin{abstract}
Disabled street vendors occupy the best licensed locations in downtown São Paulo and have done so for several decades, despite repeated attempts to remove them from the streets or open up the trade to the able-bodied. Drawing on social closure and new institutionalist theory, this paper analyzes the policymaking process toward disabled and elderly street vendors over the last 60 years. It argues that these social groups initially benefited from a policy granting them special rights, which evolved into a monopoly over street vending licenses, and that political stability during the military dictatorship (1964-1985) allowed them to accumulate nonmaterial assets such as symbolic capital and political influence. Organized disabled and elderly vendors subsequently used these assets to shape the outcomes of reforms and preserve their relative advantage, thereby constructing the unequal legacy of social closure.
\end{abstract}

Keywords Public policy $\cdot$ Social closure $\cdot$ Informal economy $\cdot$ Brazil

On May 19, 2012, the mayor of the largest and wealthiest city in the southern hemisphere, São Paulo, signed a series of municipal decrees (MDs) abolishing street trade. The decrees came in the wake of a protracted campaign to - in the words of street vendors' leaders - exterminate street vendors. On top of mobilizing military police forces to crack down on street vendors, the municipal administration of Gilberto Kassab endeavored to revoke all street vending licenses during the mayor's 6 years in office, from mid-2006 to the end of 2012. By early 2012, around 480 street vendors still had a valid license in downtown São Paulo, the commercial heart of the city. Two thirds of them were disabled or elderly. At the time the final decree came down, only 116 had a license, and $94 \%$ of them were disabled. The remaining $6 \%$ were classified as elderly.

A street vending license means the world to its holder. Despite being a precarious title that can be revoked by city officials, a license is a formal recognition by the state that the person has the right to practice street trade. Licensed street vendors set up a stall at the address

Jacinto Cuvi

jacinto.cuvi@unine.ch

1 Institut de Sociologie, Université de Neuchâtel, Fbg. de 1'Hôpital 27, 2000 Neuchâtel, NE, Switzerland 
designated on their license - their "spot" (ponto) — and trade in products ranging from garment, shoes, and bags to packaged foodstuffs. Street vendors who do not possess a license work "on the run" (na correria), constantly dodging police officers. Aside from granting its holder the privilege of stability and, thereby, enhancing her profit rates, a license offers a set of psychological rewards such as comfort and tranquility in the conduct of business as well as a very relative but genuinely experienced amount of prestige. In an occupation marked by stigmatization and shame (Estrada and Hondagneu-Sotelo 2011), license-holders - and authorities - often refer to unlicensed street vendors as "the irregulars," "the clandestine," or "the illegals."

The dominance of the disabled and the elderly in licensed street trade could easily be attributed to charity and social policy. In fact, São Paulo is not the only place where disabled and elderly street vendors are overrepresented among the licensed few, especially in the downtown area, and the municipal ordinance governing street vending in São Paulo explicitly favors the disabled and the elderly. ${ }^{1}$ Unlike in other Latin American (or European) cities where disabled people trade in tightly regulated niches such as lottery tickets, however, licensed street vendors in São Paulo can make a lot of money, either by selling wares or by illegally subletting their stall. ${ }^{2}$ On the main commercial street in the city, three informants reported that some stall owners can make as much as eight times the minimum wage. ${ }^{3}$ Moreover, the dominance enjoyed by the disabled and the elderly goes back more than six decades. Ever since a municipal decree issued in 1953 granted them priority rights in the allocation of selling spots, disabled vendors have retained the upper-hand in the trade. And they have done so in the face of regimes whose officials were hostile to street vendors as a whole or opposed to the participation of the disabled in street trade. Since the disabled have been a politically weak, neglected constituency in Brazil for a long time (Kirakosyan 2013), these historical developments call for a more elaborate explanation.

I argue that this improbable state of affairs is best explained as a legacy of social closure. In its original formulation, social closure involves both symbolic and institutional categories, the "matching" of which reinforces unequal access to resources (Weber 1978, see also Tilly 1998). Closure obtains when a group whose members are regarded as distinct from other members of society becomes eligible (or ineligible) for specific opportunities by virtue of institutionalespecially legal—-provisions. South Africa under apartheid, where Whites held exclusive rights to vote or work in certain jobs, offers a textbook example of social closure.

Most studies see social closure as a long-term, enduring sociological feature (Murphy 1984; Parkin 1974). Theories of social closure have a problem addressing and explaining change, however. Why does inequality persist over time if the people, the regime, and even the norms enforcing closure change? The legacy of closure has received less attention than closure itself. To understand this process, I draw on new institutionalist scholarship (see Hall and Taylor 1996; Thelen and Steinmo 1992). Institutionalists have established the path-dependent

\footnotetext{
${ }^{1}$ Municipal Decree 11039.

${ }^{2}$ License holders must be at the stall in case of inspection, but the practice of subletting the stall to their assistants is not uncommon. It is hard to assess the scale of this practice given its illegal character. But whether license holders use the stall to sell their own merchandise or sublet it to other vendors, they enjoy an advantage compared to unlicensed street vendors.

${ }^{3}$ In informal economies like street vending, income data are inevitably based on rough estimates. The figure cited here was provided to the author by two licensed street vendors and one storeowner and former street vendor working in the area. The figure is consistent with the highly skewed distribution of income in street trade (Bromley 2000).
} 
character of institutional arrangements, whose features and effects tend to "stick" over time through extensive reform processes (Hacker 1998; Pierson 2004). Hence the proverbial legacy of past institutional regimes. In contrast to the conventional understanding of the legacy as a product of inertia, however, this study analyzes the efforts of closed groups to secure advantages during reforms, on a tilted playfield (Thelen and Steinmo 1992). Indeed, during stable times, closed groups accumulate the nontangible returns of social closure (information, influence, legitimacy, etc.). Later, when norms of access are relaxed, the same groups use these assets to construct an unequal legacy.

To flesh out these mechanisms, I retrace the history of street vending in São Paulo since a municipal decree was issued by the mayor in 1953 and focus on the reforms carried out by the first Workers' Party (PT) administration between 1989 and 1992. The initial decree laid the foundations for social closure by granting the disabled and the elderly priority rights in the allocation of selling spots. But the long-term effects of this measure were by no means a given. Any subsequent administration could have withdrawn those special rights, and indeed more than one attempted to do so. However, I argue that the stability brought about by the military dictatorship (1964-1985) ensured the path-dependent, self-reinforcing evolution of social closure. The privileged access to the benefits of licensed street trade in the downtown area thus evolved into a decadeslong monopoly. And, during this time, the disabled and the elderly were able to organize, build political connections, and achieve recognition as an occupational group. When the rules of the game were rewritten in the wake of Brazil's transition to democracy and, as a result, the able-bodied gained access to licensed street vending downtown, disabled and elderly vendors mobilized these assets to ensure that some old norms were maintained and other norms were redrawn in accordance with their interests. The result was a partial reform that preserved their relative advantage.

\section{Inequality as a Product of Social Closure}

\section{The Mechanics of Closure}

Structural theories of inequality emphasize unequal access to resources among bounded groups or classes. While the Marxist scholarship focuses on exploitation, which entails the appropriation of resources inherent to the labor of others (Wright 1997), the Weberian approach revolves around the concept of "social closure." In this view, members of privileged groups capture a disproportionate amount of societal wealth because they bar others from opportunities to produce and/or obtain certain resources (Collins 1979; Murphy 1984; Roscigno et al. 2007). In economic terms, the privileged access to resources achieved through social closure generates a rent, that is, a level of revenue above expected revenue under conditions of perfect (market) competition (Sørensen 2000; Weeden 2002). Even though the term is commonly associated with elite groups such as the professions, it can be-and has been - applied to any group that manages to concentrate opportunities, including lower-class and disadvantaged groups (Murphy 1984). In this context, the "privileges" obtained by closed groups are specific advantages regarding access to or control over specific resources, sometimes to the detriment of their higher-ups (Waldinger 1997). Moreover, focusing on marginal or dominated strata - as this study does - offers a sharper insight into the specific payoffs of social closure compared to other advantages enjoyed by social elites. 
As conceptualized by Weber (1978, 43-6, 339-48), social closure has two mutually reinforcing dimensions. These can be analytically distinguished as symbolic and institutional closure. To legitimize-and thus secure-their socioeconomic prerogatives, privileged groups make claims to a distinctive symbolic status. The concept of "aristocracy" epitomizes this assertion of a difference of essence hinged on virtue and blood. Such symbolic construction is facilitated, moreover, by the presence of widely recognized physical and/or phenotypical differences between groups-e.g., sexual or racial differences. However, because the boundaries thus asserted are neither clear-cut nor definitive, they require "work" and "maintenance" to be sustained over time (Lamont and Fournier 1992). In fact, stabilizing these boundaries - that is, transforming symbolic boundaries into social boundaries (Lamont and Molnár 2002) - is a foremost concern of privileged groups, and various mechanisms are employed to this end (Bail 2008; Moraes Silva 2016). Much of the recent literature on symbolic boundaries has focused on cognitive and discursive mechanisms of symbolic closure such as stereotyping and stigmatization. In doing so, however, this literature has moved away from the institutional mechanisms of closure epitomized in Weber's emphasis on the legal monopolization of economic opportunities.

Yet institutional barriers erected by legal norms and other formal rules offer additional safeguards on the holdings of closed groups. In effect, formal rules stipulate the conditions of access to, as well as the rights and obligations associated with membership in, sets of ranked institutional categories (e.g., citizen, permanent resident, visitor, and undocumented immigrant). As such, the institutional framework regulates the allocation of resources and constitutes a key dimension of the stratification system. As Tilly (1998) points out, moreover, the matching of unequally endowed institutional categories with symbolically defined social categories is a key mechanism in the production of durable inequality. The pervasive effects of such "matching" on long-term intergroup inequality are observable, for example, in the experience and aftermaths of apartheid South Africa or the Jim Crow South. In Weberian terms, the matching of symbolically defined social groups with institutional categories is a way of formalizing social closure.

Yet neither Weber, nor Tilly, nor neo-Weberian scholars committed to theories of social closure have paid much attention to the impacts of changes in the institutional framework enacting closure. While suggesting that "organizational innovations" are an effective way to combat durable inequality, Tilly $(1998,36)$ falls silent on the mechanics of such innovations and the unfolding of their effects on the distribution of resources. On the other hand, scholars like Parkin (1974) and Murphy (1988) posit closure as a sociological given whose institutional forms (e.g., estates, credentialism, etc.) vary according to the economic system in place. Yet the process of transformation remains unexamined, along with its potential redistributive effects.

By contrast, the over-time allocative effects of institutions and institutional change is a foremost concern of the new institutionalist literature, especially (but not only) in its historical variant. The "codified rules of the game," as Pierson (2004) puts it, define property rights and thus allocate resources (North 1990). Moreover, institutional norms are self-reinforcing by virtue of an array of mechanisms including increasing returns, irretrievable investments, cognitive sunk costs, and so on (Mahoney 2000; Pierson 2004; Thelen and Steinmo 1992). It follows that a social group embedded in a privileged institutional category will see its advantages increase or at least consolidate over time in the absence of exogenous shocks or internal disruptions. 
Alongside the material rewards provided by the institutional framework, the cumulative nature of privilege implies that other, less tangible resources will flow (Bourdieu 1984). These include nonmaterial forms of capital such as social networks, political influence, information, and so on. And the stability of institutionalized privilege also pays symbolic dividends: it reaffirms the belief among insiders (and outsiders) that things are the way they should be or could not be otherwise. I refer to such assets as "soft assets" in contrast to the more apparent dimensions of closure, that is, the formal rules and the material resources or economic opportunities they explicitly allocate.

\section{Reform and the Legacy of Closure}

This paper seeks to explain the distributive outcome of reforms that put an end to social closure. More specifically, it seeks to understand why redistribution in such instances is partial at best. By definition, reforms are top-down modifications of formal rules undertaken by power-wielding agents. As such, reforms have the potential "open up" a group theretofore protected by closure by relaxing the conditions of access to privileged institutional categories, as with the commodification of nobility titles.

As institutionalists point out, reforms are more effective if they occur during critical junctures, that is, moments of increased uncertainty usually brought about by exogenous shocks (Capoccia and Kelemen 2007; Mahoney 2000). The outcome of critical junctures is by definition not predictable. Even then, however, contingency is not total. While some structural constraints are relaxed, others are not. And the remaining constraints limit the options available for reform and restrict the scope of change (Hacker 1998). It would therefore be misleading to depict path dependence as a matter of pure institutional inertia. In fact, the stickiness of previous arrangements during reform periods is often obtained through the efforts of power-holders with a vested interest in the status quo. Veto players who have the legal or practical ability to disrupt or shape the reform process are likely to exercise their power if the changes do not favor them (Immergut 1992).

This study builds on the above scholarship and supports the thesis of continuity based on unequal agency during critical junctures. I argue that reforms to closure are moments of active opportunity hoarding involving a struggle for the definition of the institutional framework (Thelen and Steinmo 1992). That struggle, however, is biased in favor of formerly closed groups who, during stable times, accumulate soft assets not explicitly allocated by the institutional framework. Actors then rely on these assets to secure advantageous institutional outcomes - as well as, by implication, high material returns - during critical junctures. This process can be described as the construction of the legacy. Finally, when privileged actors lose control over the redefinition of institutional norms, soft assets can also be used to stall enforcement. Given the importance of clientelistic networks in the field of street vending (Cross 1998), the formation of organizational structures and ties to political actors constitute soft assets of particular relevance in the case at hand.

\section{The Setting}

Street vending populations fluctuate according to political and economic circumstances, and street vendors are a marginal group not always covered by household surveys. These issues notwithstanding, recent estimates place their numbers in São Paulo between 100,000 and 130,000 
(Pamplona 2013). According to Pamplona (2013), two thirds of them are male, almost half did not complete elementary school (versus one fourth of the workforce), and about $40 \%$ were born in the Nordeste, Brazil's northeastern region with a predominantly Afro-Brazilian population. The historical prevalence of Nordestinos and their offspring in the trade has fueled negative stereotypes among local elites who see street vendors as dark-skinned intruders. Following Brazil's economic boom in the early 2000s and the influx of international migrants, a substantial number of street vendors also come from Africa and Latin America.

The vast majority of street vendors are unlicensed. They work on the move, constantly shifting sidewalks, streets, and street corners to elude law-enforcement agents. In addition to enduring continuous psychological pressure, unlicensed street vendors are unable to sell highvalue goods or to accumulate large stocks given the permanent risk of apprehension. Street vendors sell anything from plastic jewels and clothing items to cheap electronics, padlocks, and headphones. They carry these items in backpacks, tarps, or plastic bags. Street vendors are spread across the city but tend to concentrate in bustling commercial areas, and sometimes form small collaborative networks at specific locations to avoid confiscations. When street vendors are caught, the confiscated merchandise and equipment are normally registered by an inspector (fiscal), and street vendors receive a fine they must pay to retrieve their wares, but no charges are filed against them.

The criteria for granting licenses specified on MD 11039 are relatively strict and explicitly favor the disabled and the elderly. Disabled vendors need to provide a medical certificate as proof of their disability, and those with "serious disabilities" (e.g., blindness or paraplegia) have specific advantages when applying for a license. Over the last 15 years, however, successive municipal governments in São Paulo-as in other cities of the Global South (Cross and Morales 2007) - have enacted restrictive policies that make it almost impossible to obtain a new license, and licenses are nontransferable by law. Unless cancelled or revoked due to serious infractions or large-scale urban development, however, licenses were renewed periodically until the 2012 crackdown.

Contrary to unlicensed street vendors, who are constantly touting their products to passersby, especially in crowded commercial areas, licensed street vendors often sit back and chat while awaiting the next customers. Licensed street vendors have roofed stalls of roughly 1 by $1.5 \mathrm{~m}$, set up at fixed spots designated by the city on the license. Most licensed spots are clustered on squares or along a thoroughfare, but some isolated stalls can also be found in different parts of the city. Some stalls have wheels and can be stored away at night. Licensed vendors sell garment, handbags, leather items, shoes, toys, and packaged foods. They manage much larger inventories than unlicensed vendors and sell more valuable products (see Fig. 1). In comparison to their unlicensed counterparts, licensed vendors thus enjoy the privilege of stability in the day-to-day conduct of business. They are represented by a union, the Union of the Licensed (hereafter the Union), as well as by smaller district-based associations. ${ }^{4}$

As noted earlier, in the downtown area, about two thirds of them are elderly or suffer from disabilities ranging from blindness and paraplegia to amputations and mild psychiatric disorders. Licensed vendors with disabilities are allowed to have one or two registered aids working at their stall. Albeit illegal, some license holders lease their stall to other vendors, sometimes registered as aids, and obtain a rent. All licensed vendors I met had a house, and some owned cars. By contrast, none of the unlicensed vendors I met had a car, and some were homeless.

\footnotetext{
${ }^{4}$ I have used fictitious names for interviewees and organizations unless authorized to disclose real names by the sources.
} 


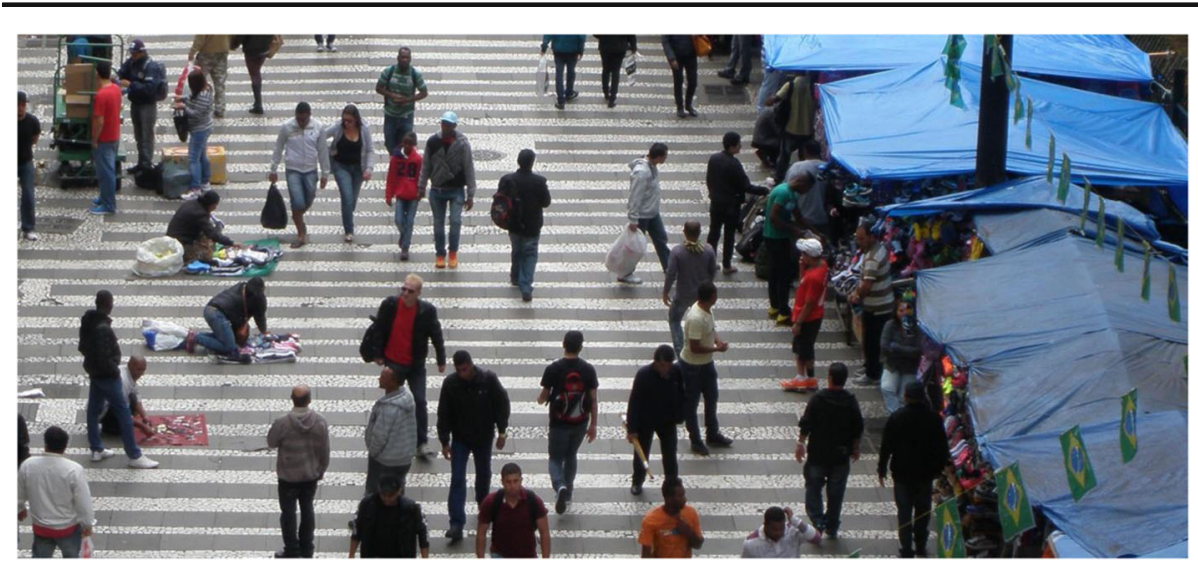

Fig. 1 Street vendors in São Paulo. Note: Licensed vendors' stalls are lined up on the right-hand side, under large plastic tarps. Unlicensed vendors are on the left, with their wares laid on the floor

The son of a well-located disabled vendor studies at a private college in the United States. And, among licensed vendors, the disabled tend to have locations closer to the foci of commercial activity as reflected in their concentration in the downtown district of Se (see Fig. 2). In fact, on 25 de Março, the main commercial street, $95 \%$ of licensed locations were occupied by disabled or elderly vendors before - and after — the Kassab onslaught. I refer to this second advantage as the privilege of centrality. Licensed disabled vendors also have their own association, the Disabled Vendors Association (hereafter DVA), which has close ties to the Union. As an additional perk, disabled vendors downtown are allowed to leave their stalls by $1 \mathrm{pm}$ and let their aids take care of business.

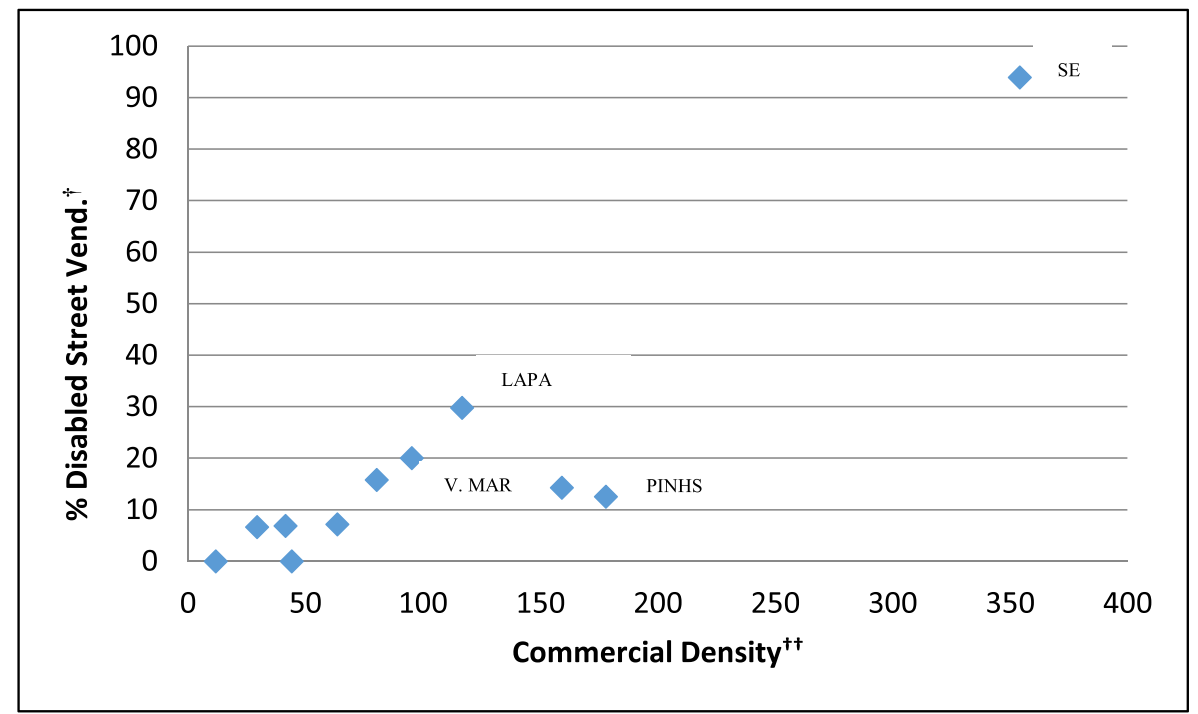

Fig. 2 Percentage of Disabled Street Vendors Against Commercial Activity by District in São Paulo** Only licensed street vendors are considered. Only districts with street vendors registered as of March 2012 are shown on the graph. 'Statistics about percentage of disabled street vendors were calculated based on official records obtained during fieldwork. ${ }^{\dagger}$ Number of commercial establishments per square kilometer based on data from the Sumário de Dados 2004 


\section{Methods}

This study relies on process-tracing - an approach that combines data sources to identify the most likely causal mechanisms shaping specific outcomes, especially during critical junctures, while ruling out competing hypotheses (Collier 2011; Fairfield and Charman 2017). Fieldwork took place over the course of four research trips to Brazil, including two preliminary summer field trips, a year-long research stay between August 2013 and August 2014, and a 1-month follow-up trip in June 2015. On the first trip I visited São Paulo along with three other cities. Subsequent fieldwork centered on São Paulo alone. I interviewed ten high- and mid-ranking city officials, nine leaders of street vendors associations, six NGO workers (three of whom were lawyers), four police officers of various ranks, three current or former city councilmen as well as three aides, two leaders of storeowners associations, two storeowners, two lawyers, and a judge. Whenever possible, interviews were tape-recorded. In addition, I observed, chatted with, accompanied, and interviewed street vendors, both licensed and unlicensed. I developed personal ties with several vendors and I repeatedly visited their stalls or spent time with them outside their work hours. I grew especially close to fourteen of them, seven of whom held or had held a license, and five of whom were disabled. In some cases, I conducted standard interviews that lasted between 10 minutes and several hours. In other cases, interviews took the form of conversations in which I inquired about issues of interest to my research. Because most conversations with street vendors happened on the streets or inside noisy coffee shops, I was unable to use the tape-recorder and resorted to simultaneous or subsequent note-taking. The high frequency of interrupted conversations, lasting chats, and other casual but instructive interactions makes it hard to provide an exact number of formal or informal interviews, but I met and talked to more than fifty street vendors.

Several interviewees played key roles in the process under study. I targeted state officials involved in policymaking towards street vendors at different points in time as well as street vendors' leaders who participated in negotiations with different administrations. Access to key informants was achieved through various channels including formal requests to speak with public figures, referrals from other interviewees, encounters at meetings, and contact during fieldwork. More than once I contacted informants directly, without referral, by approaching them at events or in the streets, visiting their office, or sending an email. I introduced myself as a researcher from a university in the U.S. doing research on street trade. I also met interviewees through other informants or networks, such as street vendors' associations or an NGO working with street vendors who invited me to their meetings. Most interviewees with institutional positions were friendly and open, and I insisted on the confidentiality of the interview. In the streets, I was perceived by street vendors as a curious but discrete outsider and something of an oddity in a setting where white foreigners are few, and fewer still display any interest in street vendors. I spoke to them in Portuguese, which I had studied for several years before starting my fieldwork, and I believe my own Latin American background helped me establish rapport given some cultural similarities.

In addition, I examined an array of official and personal documents. I gathered and reviewed 180 files concerning the regulation of street trade in the digitalized archives of the city council (including bills, hearings, vote tallies, motivations, etc.). The archives go back to 1892, and they can be searched thoroughly with keywords or by tracking documents cited in subsequent files (the search engine offers this information). I also examined newspaper articles, handouts, letters, and a book written by a key player in some of the developments recounted below. The search for documents was not based on a forethought plan but, rather, on 
finds and offers made during fieldwork. The analysis of documents relied on careful reading and interpretation, sometimes informed by inquiries with the actors concerned, but did not involve software or special coding methods. Documentary and interview data were triangulated in the reconstruction of policymaking processes. Interviews with state officials provided insights into the reasons behind policy decisions, the political forces at work, as well as the intended and unintended results of adopted policy measures. Interviews with street vendors provided information on the working conditions and strategies used by different categories of street vendors as well as on the street-level politics regarding the distribution of spots and street vending opportunities.

\section{The Structuring of Street Vending in São Paulo}

Upon his inauguration as mayor of São Paulo in 1953, Jânio Quadros set out to regulate street vending following a period of relative neglect (Bertolli 1990). Quadros's initiative was at least partially motivated by pressures from storeowners, who have traditionally regarded street vendors as disloyal competitors and an urban nuisance (Bromley 2000). During his first year in office, Quadros issued six municipal decrees on street trade. The first of these decrees, MD 2201, banned street vending from the downtown area, the commercial heart of São Paulo. By the same token, MD 2201 established the rules for the allocation of spots beyond the central region. The disabled were given preference, followed by the elderly, "those with numerous offspring," married people, and finally bachelors staying with host families. Yet any adult person had the right to apply for a spot.

Probably in response to supply problems resulting from the downtown ban, subsequent decrees created exceptions, first for sellers of lottery tickets, then for mobile fruit vendors (Bertolli 1990). A later municipal decree subdivided the city into sectors (some of which impinged on the foreclosed downtown area) and established a system of rotation among licensed vendors, limiting the occupation of each spot to two weeks in an effort to spread the benefits of centrality more evenly. The last of the six decrees exempted the disabled and the elderly from the rotation system, thus guaranteeing them a stable hold on their spots. Albeit real, the advantages thus achieved by the disabled and the elderly were relative insofar as other social groups could also hold a license and/or trade downtown. Moreover, they were precarious: MDs are lower-order regulatory instruments that can be easily overturned by other MDs at the discretion of subsequent mayors or overridden by municipal laws (MLs).

In fact, under Quadros's successor, Adhemar de Barros, pressures from storeowners against street vendors intensified. Using their political influence inside the city council — which, in Brazil, has legislative powers - storeowners' associations pushed for a ban on street vending for all social groups. While the bill imposing the ban did not delimit a specific area, it targeted mostly the downtown area and was approved by the council in 1957. That same year, however, the city council passed a new municipal law (ML 5440) which was put forth by the mayor himself. Claiming it would be "inhumane" and "contrary to Christian values" to remove the disabled and the elderly from the downtown spots which they already occupied, the bill called for an exception for these groups while granting them tax exemptions. Given the precedence of MLs over MDs, this law became the overarching norm for policymaking in street vending for more than three decades.

In new institutionalist parlance, the initial conditions that set the path to dominance by the disabled in licensed street trade were "contingent" (see Mahoney 2000). Of course, a range of 
circumstances, both personal and political, led Quadros to adopt disability as permit-granting criteria and de Barros to shield the disabled and the elderly from eviction. Christian values may have played a role, along with other, less high-minded considerations. ${ }^{5}$ But those circumstances do not matter from the perspective of the analytic question at hand, namely: Why did the disabled retain their dominance in the long run, notwithstanding far-reaching political and institutional change? Moreover, at the time, things could easily have played out differently because the position of the disabled in street vending was not yet institutionalized, and nothing in our theory is meant to explain why Quadros made his initial decision to prioritize the disabled and why de Barros succeeded in his efforts to spare them from the ban. This is a causal story about the unexpected long-term consequences of these developments.

In 1964, a military coup placed Brazil under a military dictatorship. Draconian law-andorder legislation was adopted across the country restricting freedom of movement and outlawing the "unproductive" occupation of public spaces as "loafing" (vadiagem). In state capital cities like São Paulo, the mayors were appointed by the military regime. Policy towards street vending followed a top-down logic, alternating between the cancelation of all licenses and efforts at sharpening and tightening regulations. In 1974, then-mayor Miguel Colassuono made a short-lived attempt to open up street trade to other groups through a municipal decree (MD 11214). His successor reinstated the disabled and elderly vendors' exclusive access to licenses. Hence, the framework established by ML 5440 prevailed, guaranteeing a monopoly over licensed street vending to disabled and elderly vendors located in the downtown area. Although licenses had to be periodically renewed, another municipal decree (MD 14396) dating from 1977 introduced a seniority rule by which street vendors with the most time on the streets had priority in the selection of their spot during renewals.

The rights granted to the disabled and the elderly led to their organizing into an association, the ABRADEF, which later branched out into another association, the DVA. When a working group was established by mayor Mario Covas in 1983 with the task of designing a lasting policy for street vendors, representatives of disabled and elderly vendors were invited to the table. Not surprisingly, the decrees that came out of the working group reserved fixed spots in the central district to "seriously disabled" vendors while authorizing spots beyond that area for other disabled and elderly street traders. The able-bodied were only allowed to circulate in the outskirts with so-called "human-propelled carts." Despite a continued tug-of-war between the city and street vendors, this arrangement held under the second administration of Jânio Quadros, between 1986 and 1989, following Brazil's return to democratic rule in 1985.

The 35-year-long period running from Quadros's first mayoral administration before the 1964 coup to his second administration after the return to democracy began with a concession of special rights to specific social groups, namely, the disabled and the elderly. Those special rights laid the basis for closure even though, at the time, closure was still partial and "fresh"that is, not institutionalized. Still, the measure set a policy precedent and incentivized the organizing of these groups in the long run. Moreover, almost two thirds of this period unfolded under a repressive military regime. While the period was not unusual in the oscillation between repression and concession that characterizes policy toward street vending across the Global South, it brought about stability by precluding the incorporation of other constituencies into legal street vending. Indeed, during all those years, the political system was impervious to potential demands of able-bodied vendors, who were compelled to work in the outskirts of the

\footnotetext{
${ }^{5}$ Rumors circulated that an informal tax levied on disabled vendors by city inspectors went to a social policy fund set up by the mayor's wife (Bertolli 1990).
} 
city or in the shadows, running from law-enforcement (MSP 1990). As a result, the legal framework set by ML 5440 remained unchanged. In other words, the dictatorship had a "lockin" effect (Pierson 2004), as institutionalists put it, on the path set by the previous period; it enabled the institutionalization of closure. However, the political landscape was to change dramatically following the election of Luiza Erundina, the Workers' Party candidate for mayor of São Paulo, in 1988.

\section{9-1993: The Reform}

As predominantly dark-skinned outsiders in a marginal trade, street vendors from the Nordeste in São Paulo faced hostility from the notoriously conservative local elites. In this context, the unexpected coming to power of Erundina, a social worker from the Northeast belonging to the leftist Workers' Party, gave rise to two diverging interpretations among the public. ${ }^{6}$ For the socioeconomic elites, it meant chaos. For the working classes, especially for those who had migrated from the Northeast, it meant freedom. And so, in a climate of nationwide expansion of civil liberties coupled with high unemployment rates and economic depression, the streets "exploded" with street vendors.

As recounted by Aldaiza Sposati, the top public official in charge of street vending policy at the time, the PT leadership was worried about potential attempts by conservative sectors to sabotage the government and brand it as incompetent. The two strategic areas where a boycott was expected were trash collection and street vending. In both sectors, city officials were aware of the need to impose order and show results. At the same time, it did not take long before demands from groups of able-bodied street vendors working without licenses in the outskirts of the city made themselves heard - and their demands found echoes among radicalized groups within the ruling coalition.

The challenge faced by city administrators was compounded, moreover, by the absence of an established framework of urban governance. A new national constitution had been adopted a year earlier, in 1988, and the division of tasks and attributions among the different levels of government had yet to be defined and implemented. In fact, the so-called General Law of the City (Lei Geral das Cidades), which establishes the legal prerogatives and duties of city governments, was not passed until 1990. As one district administrator put it, "the rules of the game were in the making."7 And so, at the local level, the norms of urban governance had to be "invented" in a context marked by improvisation and fire-fighting.

This scenario contains all the ingredients of a critical juncture. There is uncertainty, fluidity, and a wide window of opportunity for changes to the institutional framework. Until then the "game" was predicated on closure, but the rules were changing, and the underlying patterns of resource allocation could be expected to change. That change was limited, however, for reasons discussed below.

The first step taken by the new administration to stem the rising flow of street vendors was to distribute tickets to all street vendors found on the streets on the fourth day following Erundina's inauguration. Ticket-holders had to then register with the city and produce proof of their longtime involvement in street trade (i.e., notices of confiscation, testimony from reliable witnesses, etc.) to receive a provisional permit that would later be converted into a license based on the availability of spots. As it turned out, the distribution of tickets occurred during a

\footnotetext{
${ }^{6}$ Interview with party member and city official, February 2014.

${ }^{7}$ Interview with party member and city official, February 2014.
} 
holiday period when many longtime street vendors had gone back to their hometown in the Northeast. Their complaints prompted the city to issue a new call by which other street vendors who could provide evidence of previous experience in the trade also received a permit. In this process, too, the disabled were given priority (MSP 1990).

The purpose of distributing tickets was to take stock of the growing population of street vendors. After this information was collected, legislation needed to be crafted to determine who could sell legally, when, and where. Various stakeholders were invited to the table, including representatives from the longstanding organizations of disabled and elderly street vendors as well as informal leaders of able-bodied street vendors who emerged more or less spontaneously at the time to voice their demands. Negotiations carried on for weeks through a series of heated meetings. An attendant recalls one of the meetings:

One of the able-bodied would say: "We are all equal. We all have the right to work." A furious disabled man would reply: "Oh yeah, you think we are equal? Why don't you come here, let me poke out your eye, let me break your arm... Let's see how equal we are." (...) That meeting ended at the police station. ${ }^{8}$

This dramatic statement shows how deeply entrenched the association between disabled and licensed was in the worldview of disabled vendors at the time. The statement also captures the sense of entitlement that develops within a symbolically bounded social group when exclusive rights are held by its members for a long time. In this case, the symbolic boundary was grounded in bodily condition. From the speaker's point-of-view, vendors could not hold the same rights if they had different bodies. Even now, according to an able-bodied licensed vendor, disabled vendors "cannot [accept] that an able-bodied vendor may occupy a better location." 9

The views held by disabled vendors could be dismissed as a self-interested construction of reality, but the influence of these views extends beyond those sharing them. In fact, the top policymaker on street vending in the PT administration, who recounted the exchange, said, "[The disabled and the elderly] had been [on the streets] for a long time. They had that right." 10 In short, social closure has symbolic effects on the perspective of outsiders, too. Her views on the matter are especially revealing considering her own personal convictions about disabled people. As a social worker, she saw the streets as the "worst place" for the disabled and the elderly to be, given pollution, traffic, and related health hazards. And yet she felt bounded in her decision-making by the rights these groups claimed on the basis of their history. This incident also provides evidence against the thesis that the upholding of the inherited rights of the disabled by the PT administration was, like the original granting of such rights, motivated by charitable social policy considerations.

At the same time, according to the account offered by one of the longstanding leaders, the leadership of the disabled and elderly vendors understood that things were going to change. The question was how big a share of the (licensed) market they would have to surrender. The proposal drawn by the stakeholders' working group suggested leaving only $20 \%$ of licenses to the able-bodied - a reflection of the disabled vendors' outsize influence. As it happened, these quotas were also a matter of heated debate within party ranks. The compromise adopted in MD 27660 , issued on February 22, 1989, allowed disabled and elderly vendors to request first up to

\footnotetext{
${ }^{8}$ Interview with Aldaiza Sposati, January 2014

${ }^{9}$ Conversation with able-bodied licensed vendors, November 2013.

${ }^{10}$ Interview with Aldaiza Sposati, January 2014.
} 
two thirds of licensed spots. The other third went to able-bodied vendors, along with any spots allotted to but not claimed by the disabled and the elderly. The latter were thus given priority in the selection of spots, and the seniority rule was maintained. Finally, a consultative body called CPAs, which was composed of a host of actors representing the state, street vendors, business interests, and other sectors of civil society, was established by that same decree with the mandate of deliberating on decisions affecting street vendors at the district level. Out of 11,000 requests for permits following the initial distribution of tickets, only 2200 applicants were given a license - though more licenses would be issued later. The number of disabled and elderly among them is unclear (MSP 1990).

The struggle pitting the disabled and the elderly against the able-bodied during this reform period was, at first, a struggle for the definition of the broad institutional framework. It was a struggle over the terms of closure - its constitutive rights - which were to be relaxed to include other groups. The new framework marked a transition from total to partial closure that reflected the symbolic and political capital mobilized by disabled and elderly street vendors during the reform.

After that framework was defined, the focus of the struggle shifted to its implementation. Despite the quotas for licenses established in the decree and the consultative role granted to the CPAs, the power of issuing and canceling licenses was left in the hands of district administrators who delegated such tasks to their subordinates. In the downtown district of Sé, where the most profitable spots were located, the struggle to define "the who, the when, and the where" of street vending was particularly intense. The limited staff could hardly cope with the mass of unlicensed street vendors and many inspectors hired under previous administrations were suspected of corruption. ${ }^{11}$

Access to officials with decision-making powers thus became a key asset for street vendors. For their part, city officials were looking for civil society partners to help them police the streets. As Cross (1998) notes, resource-wanting state authorities tend to rely on leaders of street vendors' organizations to implement their policies. In the recollections of a city employee, the larger the number of street vendors that a given leader could mobilize, the more the city would be willing to engage in negotiations with her. Many associations of street vendors flourished in this context, some of which had but a handful of followers. Once again, in this landscape, longstanding organizations of disabled and elderly street vendors had an edge. As legitimate interlocutors with a large and established following, leaders of these organizations briefed local officials on attempts by other groups to "take over" the streets. "In order to evict the newcomers, we had to ally ourselves with the established ones," a district administrator explained in an interview. ${ }^{12}$

In the midst of this urban drama, storeowners did not sit by idly. Having lost their influence over the executive branch, they resorted to the city council. In 1989, councilman Bruno Feder, whose party, the PL, represented the interests of local commercial elites, put forth a bill aimed at setting limits to what Feder described as "urbanistic terrorism" (i.e., the uncontainable spread of street vendors across the city). ${ }^{13}$ While drawing largely on the decree issued by the Erundina administration, the bill introduced a 2-year expiration date for licenses and established the mandatory requirement of having lived in São Paulo for 7 years to be eligible to hold a license. The bill, which prompted mass protests by street vendors, was vetoed by the

\footnotetext{
${ }^{11}$ Interview Rubens Possati, chief regulator of street vending in Sé, November 2013.

${ }^{12}$ Interview with the author, February 2013.

${ }^{13}$ Interview with Bruno Feder, November 2013.
} 
mayor but eventually approved by the city council with the absolute majority needed to override the veto. Organized street vendors' leaders, however, drew on their political influence to convince Feder to submit another bill "correcting the previous one." The second bill, which was also approved by the council, reestablished the seniority rule and rescinded the requirement of 7 years of residence in São Paulo.

At the end of Erundina's administration, the able-bodied had gained access to the category of licensed street vendors, crossing the threshold of both stability and centrality. ${ }^{14}$ But the disabled and the elderly had secured their relative advantage on both counts. They still enjoyed the privilege of stability through quotas on licenses, and they preserved the privilege of centrality through priority rights in the selection of spots coupled with the maintenance of the seniority rule. The seniority rule in particular attests to how, by mobilizing the political and organizational capital accrued under the previous period, disabled street vendors secured norm transfers through this critical juncture, which preserved patterns of inequality created by closure. Finally, the practical challenges of policy implementation gave them an additional edge: they developed ties to party and state officials, thereby building up more political capital in the long term.

\section{The Aftermath}

The mechanisms laid out in the theory section are more readily observable during the critical years of the Erundina administration. It was during that time that closure came to an end, even though disabled and elderly vendors maintained strategic advantages embedded in the new institutional framework, in line with the thesis on the legacy of closure. To understand the comparatively advantageous position some disabled street vendors still enjoyed two decades later - as reflected in the previously outlined distribution of stalls during fieldwork - a look at the fate of that legacy is in order.

For several years, the institutional framework put in place under Erundina, which favored the disabled and the elderly in both direct and indirect ways, was worked on by the established leadership of street vendors to accrue marginal benefits. Some elite blending also took place. In the mid-1990s, the association representing the disabled street vendors allied itself with a group of licensed, able-bodied street vendors from downtown and founded the Union. The Union achieved legal recognition and became the official representative of licensed street vendors in the city. At the same time, the ties developed between street vendors and key figures within the Erundina administration allowed street vendors to shape the contents of a bill sponsored by two city council representatives from the PT-which granted leaders of street vendors associations control over the distribution of licenses - even though the bill ultimately failed to pass.

On the other hand, unlicensed street vendors had proliferated under the Erundina administration and some had coalesced into associations or gangs that exerted de facto control over specific areas. Moreover, the two scandal-ridden administrations that succeeded Erundina did not regard street vendors as their electoral constituency. Two investigations carried out by two city council investigatory committees (Comissão Parlamentar de Inquérito or CPI in Portuguese) in the mid- and late 1990s disclosed a large network of bribe-taking and extortion involving state agents ranging from street-level inspectors to a state congressman. At the head of these giant extortion system known as the bribes' mafia or the inspectors' mafia - which

$\overline{{ }^{14} \text { Some able-bodied had managed }}$ to obtain licenses downtown through informal relations with city officials. 
also extended to established formal businesses - were, according to official reports, powerful politicians who controlled specific "districts" where they appointed administrators loyal to them. Part of the money collected served to finance electoral campaigns. As described in the committee's reports and testimonial evidence, city officials collected weekly bribes from street vendors to allow them to work at particular spots, printed and sold false licenses, embezzled wares apprehended from street vendors, and charged unlawful fees to return merchandise to its owner, among a wide array of other crimes including an illicit deal to force street vendors to buy overprized stalls from a specific supplier. The CPI report also indicates that some street vendors participated in the extortion as middlemen who collected bribes from other vendors. The investigation made waves and led to retaliatory action by the mayor, who threatened to relocate all street vendors inside enclosed markets, but the benefits enjoyed by the disabled were never in question. As the wife of a longtime disabled street vendor once put it: "The law belonged to the disabled." 15

Her words express the previously encountered conviction that the rights of disabled street vendors are grounded in something deeper than changing regulations. There is an underlying symbolic economy, shaped by history, in which disability is associated with the right to a license and from which disabled street vendors derive their legitimacy. Symbolism, however, wears out, especially when no longer sustained by clear-cut institutional boundaries. But disabled vendors retained their political influence. Several disabled street vendors cooperated with the PT councilman who was leading the investigative commission into the inspectors' mafia, including a longtime leader who denounced the forced purchase of marked-up stalls. The publicity acquired by the case spurred the councilman's political carrier- he rose to become federal minister of justice and then attorney-general under a subsequent PT presidency. In short, disabled street vendors were able to weather the crisis and shape the outcome while less established vendors paid the price.

Far from ushering a new opening, the return of the Worker's Party to the mayoralty in 2001 strengthened the hand of the established licensed street vendors' leadership. Although policing was relaxed and many unlicensed street vendors took to the streets, only a fraction of new applicants were granted a license, and some licensed vendors were removed from their spots. The same official who, in the past, had been at the frontline of tough negotiations with street vendors' leaders was appointed coordinator of street vending policy across the city. By then, he had endorsed the "conservative" agenda of the established leadership of the Union, with whom he had developed personal ties. In 2002, the city launched a licensing program based on a roster of licensed vendors established in 1998. According to Union documents, that rosters contained 2593 vendors in the downtown district, 833 of whom were disabled (32\%). Vendors on the roster wishing to retain their license had to register with the city. In the downtown area, 2252 did so, including 766 disabled (34\%). In the meantime, the CPA debated the number of licensed spots to be made available in the downtown area. City officials settled on 1633, and disabled vendors were given priority in the selection of those spots (MSP 2002). By June, 1400 licenses had been granted, 671 of which went to disabled vendors (44\%). In the words of a storeowners' representative who played an active role in the negotiations, only the "upper crust" ( c crema) of licensed street vendors remained on the streets. Former Union affiliates complained in interviews about how, by sitting at the CPAs and having access to city officials, the peddler's "aristocracy" was able to punish nonaffiliates or dissenters and benefit the ruling clique.

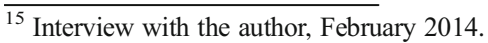


In 2004, the Workers' Party lost the city government to Jose Serra, a member of the centerright PSDB party with close ties to business elites. A year later, Serra ran successfully for governor of the state of São Paulo, leaving his vice-mayor Gilberto Kassab in his seat. An ironfist politician with hygienist values of urban development, Kassab immediately undertook to "clean out" the city. In 2006, the Kassab administration pushed for a controversial project entitled "Clean City." According to many street vendors, pressures to evict them intensified and inspections grew more frequent, leading to the cancelation of many licenses. In the mayoral elections of 2008, Kassab was elected for another 4-year term.

Kassab was also a vice-president of São Paulo's largest association of storeowners, the ACSP. Drawing on his political and personal ties to the head of the state government, the mayor signed an agreement with the military police - a police force operating under the helm of the state government - according to which the city would hire off-duty military police officers to patrol street vending. Concurrently, high-ranking retired military police officers were appointed to the head of all district administrations, where policy toward street vending is implemented, as well as to the head of the Secretaria de Coordenação das Subprefeituras, where citywide policy guidelines are drawn. After these steps were taken, the campaign against street vendors - which street vendors describe as an attempt at "extermination"continued unabated, reaching its peak in May 19, 2012, when all standing licenses were revoked in a series of decrees and administrative acts.

In the run-up to the final blow, two separate networks made attempts to counter the policy. On one front stood the Union and the DVA, which relied on their political patron, a PT council man, and resorted to "informal politics" (Cross 1998) to lobby the city government for restraint. Concurrently, an NGO with a small team of lawyers and an urban geographer who had articulated a forum of street vendors disaffected with the Union staged small demonstrations boycotted by the Union leadership. In March 2012, news broke that a public defender had obtained a preliminary injunction forestalling the eviction of a concentration of licensed street vendors in a neighborhood of the outskirts of the city. The NGO lawyers reached out to the public defender and, together, filed a class-lawsuit on behalf of all street vendors affected by the policy citywide since 2005 . The case was assigned to the same judge, who granted another injunction staying the eviction of licensed street vendors pending the final ruling. However, this court order only applied to vendors whose licenses had been canceled or revoked in 2012. After a series of appeals by the city and conflicting rulings, the injunction was upheld by a panel of 25 magistrates of the state Justice Tribunal and a federal high court (see Cuvi 2016). ${ }^{16}$ By then, the Union had abandoned its lobbying strategy and began organizing protests. At one protest, which was also attended by the participants of the forum set up by the NGO, seven disabled street vendors chained themselves to posts in front of the Justice Tribunal. Because the lower court judge had set a cut-off mark at 2012, however, only those street vendors whose licenses had been revoked or cancelled in 2012 were allowed to return to the streets. All others would have to wait until the case was ruled or the parties reached a settlement.

A working group was set up between the city and the plaintiffs to negotiate a settlement. Other stakeholders were invited, in particular the leadership of the Union and the DVA. After 8 months of negotiations, however, the group had failed to reach an agreement. Two years later, the injunction was still in force, and only those whose licenses had been canceled or revoked in 2012 were legally entitled to work. As noted earlier, before Kassab gave the coup

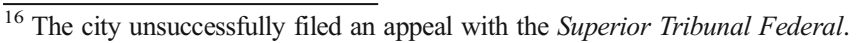


de grace in May 2012, all of the street vendors still holding a valid license in the downtown district of Se, where most street-level commercial activity is located, were either disabled or elderly. Thanks to the court order, the number of vendors entitled to work downtown increased to 480 . Two thirds were disabled or elderly.

It is noteworthy that the actors who filed the lawsuits and obtained the court order that, as everybody now agrees, ensured the survival of licensed street vendors as a professional group ("salvou a categoria"), were committed to broad ideals of expanding the "right to the city" and promoting decent work for all marginalized categories, licensed and unlicensed, disabled and able-bodied alike. The NGO workers, moreover, were involved in a political struggle with the organization representing the disabled and elderly vendors. In sum, the plaintiffs' goal was not, by any means, to protect the interests of licensed street vendors alone, and even less to preserve the market dominance exercised by organized disabled and elderly street vendors. Moreover, the judicial decision to set the cut-off line at 2012 was largely independent from the interplay of political forces in the field.

And yet, the fact that the disabled and the elderly were among the last survivors of the campaign to eliminate street vending, especially in the downtown area, was not random. While the staff of the licensed vendors' political patron as well as Union leaders complained that the city did not listen to their pleas, and their efforts were ineffective at curbing the broader agenda of "extermination" pushed by the mayor, both the PT councilman and the president of the Union developed personal ties to the district administrator in the downtown area. The latter declared in an interview that he obliged them both with numerous concessions on the enforcement of sanctions against vendors. Moreover, as I observed at several meetings, disabled vendors in particular form the electoral basis of the councilman. It is likely, therefore, that, in a context of heightened repression, an economy of favors allowed some disabled and elderly vendors-especially longtime vendors belonging to or connected with the leadership - to stay in business for longer, until 2012, and thus to benefit from the court order. The leadership of disabled vendors also benefited from access to information through meetings and contact with civil servants in a context in which threats and misinformation ran rampant, and missed administrative deadlines could cost you your license.

In short, the latter period witnessed an attempt at extinguishing street trade by abolishing the institutional category of licensed street vendor. As a city official later put it, from the standpoint of the city, "street vendors no longer exist." As legal street trade came to the brink of extinction, so did, by implication, the majority share held by disabled and elderly street vendors. The disabled and the elderly had lost the struggle for the definition of the institutional framework. Yet the links forged between them and local politicians provided them with other assets, including information and political influence, which they could mobilize punctually to ensure their individual survival and their survival as a minority within the targeted group. Although the role of political capital in this critical juncture should not be overstated - after all, many disabled and elderly vendors lost their license, and the city administration grew increasingly deaf to the vendors' demands - it is not possible to account for the distribution of licensed stalls across groups, even in the wake of a mass-eviction campaign, without considering the prior history of policymaking and the imprint that the disabled left on it. 


\section{Discussion}

This paper accounts for the resilience of intergroup inequality through reforms that challenged an instance of social closure. In the early 1990s, the boundaries of the institutional category enforcing closure (i.e., the category of licensed street vendors) were revised to include members of social groups hitherto left aside. The result was a partial opening through which the disabled and the elderly maintained their relative advantage. They did so by ensuring that certain norms contributing to social closure were transferred (i.e., the seniority rule) or redrawn in favorable terms (i.e., a legal monopoly became a system of quotas). And they obtained this outcome because the social categories who benefit from social closure accumulate soft assets such as legitimacy, organization, and political influence that allow them to shape the course of transitions.

Later, the crackdown under Kassab tried to do away with licensed street trade altogether. But, then again, soft assets such as networks and information allowed a minority of disabled and elderly street vendors to retain their licensed status until a court order stalled the enforcement of the ban. The political capital built over the years by disabled and elderly vendors was not sufficient to stop the eviction campaign, and the judicial decision to spare a fraction of licensed street vendors was exogenous to their politics. But the high proportion of disabled and elderly street vendors among those contemplated in the court order was not random. It stemmed, at least in part, from informal exchanges of favors and information to delay the revocation of their licenses in the run-up to the ban.

Like any other concept, closure is susceptible to semantic appropriations that alter or dilute its meaning. In some studies, closure is conceived broadly as the construction of bonds among members of a specific organization or the discrimination against a particular group, irrespective of formal membership criteria (Roscigno et al. 2007; Weeden and Grusky 2005). The definition put forth in this study is more restrictive. It entails a mechanism that formally restricts eligibility as well as a symbolic categorization of insiders as, in this case, "disabled" or "elderly." The institutional mechanism of closure - namely, the issuing of street vending licenses - is analogous to licensing devices used by the professions and other groups (Abbott 2014; Collins 1979; Kalleberg et al. 1981). As closure theorists recognize, moreover, such institutional devices adapt to changes in the environment in order to perpetuate advantage (Parkin 1974). But who exactly they protect and how effective they are at doing so is uncertain in the absence of a demographic specification of the closed group. By selecting a case in which symbolic and institutional boundaries overlapped - in line with the original Weberian concept of closure - this study shows that closure is instrumental for insiders in the long run, beyond its formal lifetime.

The question of sociability is relevant nonetheless. In its common understanding, closure implies complicity among insiders - a form of group consciousness akin to class consciousness in Marxist theory-along with strong and dense within-group ties. Signs of group unity are observable among the disabled, who felt entitled to licenses as a social group. ${ }^{17}$ They are also organized in defense of their interests. Moreover, some of the disabled licensees I met knew each other well and spent time together. In the downtown area, they frequently had lunch at a subsidized restaurant, where they all sat at the same table and socialized cheerfully. They also did not interact much with able-bodied unlicensed vendors. But their social life was by no means restricted to fellow disabled vendors, and rivalry among some of them was not unheard

$\overline{{ }^{17} \text { See disabled vendor's quote on }}$ p. 15. 
of. Divisions among peers is common in groups protected by social closure, however, especially in the professions where social agents are in competition with each other. In fact, animosity may be stronger within closed groups than across their boundaries, as insiders feel more threatened by other insiders who have cleared entry barriers. Conversely, Orrico (2015) found that sidewalk vendors on Venice Beach, where there is no licensing procedure, develop trust among each other to manage uncertainty in their trade, and that trust allows them to fend off outsiders in the absence of institutional barriers. This fact suggests that social capital is more important among unlicensed vendors who, lacking protection and recognition from the state, have to join forces in small groups and fend for themselves.

Yet even licensed street vending belongs to the realm of economic activity known as the informal economy where legal norms are, by definition, loosely enforced (Castells and Portes 1989; Fernández-Kelly and Shefner 2006). Corruption and coercion govern, to a large extent, the distribution of opportunities, especially (but not only) among unlicensed vendors. When formal norms are taken into account in studies of informality, they are seen as having mostly negative effects such as imposing obstacles to business development (De Soto 1989), serving the extortion purposes of corrupt law-enforcement agents (Cross 1998), or enhancing uncertainty by creating contradictory mandates (Fernández-Kelly and Shefner 2006). At the same time, students of street vending recognize that some institutional provisions such as the granting of licenses create hierarchies within the field, and protect license holders from the most egregious forms of abuse (Bromley 2000; Cross 1998; Hansen et al. 2013). Moreover (and crucially), while some norms are routinely transgressed, others are strategically enforced. Enforcement or lack thereof is neither random nor neutral. Despite structural limitations associated with state capacities, enforcement is often applied or withheld in targeted fashion at the behest of dominant players inside and outside the field (Ledeneva 2006). And the material and immaterial assets bestowed upon closed groups serve precisely to channel enforcement. In particular, political connections and access to information are critical assets in informal economic settings (Cross 1998; De Soto 1989; Holland 2015). Social closure favored the accumulation of these assets.

Other studies of street vending and other informal trades also highlight hierarchies overlooked in popular representations of informality (Ramirez and Hondagneu-Sotelo 2009; Rosales 2014). While these hierarchies need not rest on institutional norms, and hard assets such as economic capital determine to a large extent who works where and for whom (Rosales 2014), licensing procedures also create shades of informality between, for example, licensed landscape contractors, semi-formal independent gardeners, and undeclared apprentices in Los Angeles (Ramirez and Hondagneu-Sotelo 2009). It is interesting that nonmaterial resources such as social and legal capital (i.e., being a citizen or permanent resident) facilitate mobility between these occupational categories. The present study shows how those-and other immaterial-assets are also used to restrict access into higher-ranking groups.

Of course, inequality stems from numerous, intersecting factors, and no single dimension can account for complex stratification patterns, even in street vending. Neither being disabled nor having a license guarantees a place in the top 1,5 , or $10 \%$ of income distribution in the field. On busy streets, experienced unlicensed vendors can make more money than a licensed stall owner in a quiet neighborhood, even if the former endure more risks and stress. Besides, not all members of closed social groups benefit from social closure. As noted above, some disabled and elderly street vendors were 
manipulated (if not exploited) by others. And not every disabled or elderly person in São Paulo had access to a street vending license. As Weber $(1978,44)$ notes, "there are various ways in which it is possible for a closed social relationship to guarantee its monopolized advantages to the parties... [Such advantages] may be appropriated by individuals or sub-groups on a permanent basis. [This] is a case of closure within, as well as against outsiders."

In time, moreover, some able-bodied vendors gained access to better opportunities than other members of the "old guard." These empirical complexities follow, in part, from the existence of within-group disparities among the disabled and the able-bodied. Although the limited scope of this paper prevents us from discussing how these inequalities came about, it is conceivable that skilled able-bodied street vendors would achieve higher rewards than lowstatus disabled street vendors after the first opening process (and even before then). But this variation does not invalidate the theoretical argument according to which the disabled accumulated and mobilized soft assets to secure their advantages over time.

Focusing on marginalized groups such as the disabled and the elderly yields another analytical benefit. The tendency to treat social closure broadly as the secluding homophily of social elites who control prestige and power (Khan 2012) makes it difficult to isolate the specific effect of closure from the more general effects of social domination. In moments of social change, dominant groups use their power to safeguard their perks - and their power. But this study shows that social groups need not be dominant in the first place to benefit from closure through reforms. By considering non-elite groups such as the disabled and the elderly, I am able to flesh out the payoffs of social closure net of decision-making power in the course of reform and show that closure contains the seeds of its own reproduction. In fact, this perspective echoes other studies of closure which, despite relying on a networkbased rather than an institutional perspective, also consider ways in which groups at the bottom of the socioeconomic ladder such as low-skill immigrant workers can concentrate opportunities against their supervisors' best interest (Waldinger 1997). At the same time, I hope to have shown that regarding licensed disabled street vendors in São Paulo as a protected minority who benefitted from social policy (rather than social closure) fails to recognize the efforts that disabled vendors made over the years to defend their special rights against hostile administrations.

Despite the myth of a global society in which explicitly exclusionary norms are dying out, understanding the institutional mechanics of social closure is still relevant today. For one, societies and social settings with explicit rules of exclusion against women, ethnic groups, religious groups, and other collectivities abound. Moreover, even in the Western world, the legacies of social closure continue to shape patterns of inequality in the present. The analysis above offers some hints at the causes. In particular, it encourages us to look beyond the familiar faces of privilege (e.g., gender or race) into the specific institutional systems that supported it and, beyond that, into the hidden payoffs accumulated by privileged groups and the ways in which such payoffs served historically to sustain patterns of resource allocation. For example, in South Africa, interracial inequalities grew after the end of apartheid, when Blacks and Whites became equal before the law. Notwithstanding the merits of other explanations whose survey lies beyond the scope of this study, this analysis invites us to take a look at the soft assets accumulated by White South Africans during apartheid (e.g., legal and bureaucratic expertise) and at the ways in which these assets were mobilized during the negotiations that ended apartheid in the early $90 \mathrm{~s}$. 
Acknowledgements I am grateful to Ari Adut, Javier Auyero, Manuel Balán, Fred Block, Daniel Fridman, Nadya Araujo Guimarães, Erik Martinez-Kuhonta, Philip Oxhorn, Bryan Roberts, and participants at a PhD dissertation workshop at McGill University for their comments and suggestions. This research was supported by a Doc.Mobility grant from the Swiss National Science Foundation, a Doctoral Dissertation Research Improvement Grant from the National Science Foundation (award number 1434160), and a studentship from the Foundation for Urban and Regional Studies.

Publisher's Note Springer Nature remains neutral with regard to jurisdictional claims in published maps and institutional affiliations.

\section{References}

Abbott, Andrew. 2014. The system of professions: An essay on the division of expert labor. Chicago: University of Chicago Press.

Bail, Christopher A. 2008. The configuration of symbolic boundaries against immigrants in europe. American Sociological Review 73: 37-59.

Bertolli, Cláudio. 1990. Os trabalhadores ambulantes na cidade de sao paulo: Aspectos historicos. In Os ambulantes e seu trabalho: Um projeto de institucionalização, 83-125. São Paulo: Município de São Paulo.

Bourdieu, Pierre. 1984. Distinction: A social critique of the judgement of taste. Cambridge: Harvard University Press.

Bromley, Ray. 2000. Street vending and public policy: A global review. International Journal of Sociology and Social Policy 20: 1-28.

Capoccia, Giovanni, and Daniel R. Kelemen. 2007. The study of critical junctures: Theory, narrative, and counterfactuals in historical institutionalism. World Politics 59: 341-369.

Castells, Manuel, and Alejandro Portes. 1989. World underneath: The origins, dynamics, and effects of the informal economy. In The informal economy : Studies in advanced and less developed countries, ed. Alejandro Portes, Manuel Castells, and Lauren A. Benton, 11-40. Baltimore: Johns Hopkins University Press.

Collier, David. 2011. Understanding process tracing. PS: Political Science \& Politics 44: 823-830.

Collins, Randal. 1979. The credential society: An historical sociology of education and stratification. New York: Academic Press.

Cross, John Christopher. 1998. Informal politics: Street vendors and the state in Mexico City. Stanford: Stanford University Press.

Cross, John, and Alfredo Morales. 2007. Street entrepreneurs: People, place, and politics in local and global perspective. London: Routledge.

Cuvi, Jacinto. 2016. The politics of field destruction and the survival of São Paulo's street vendors. Social Problems 63: 395-412.

De Soto, Hernando. 1989. The other path: The invisible revolution in the third world. New York: Harper \& Row.

Estrada, Emilio, and Pierrette Hondagneu-Sotelo. 2011. Intersectional dignities: Latino immigrant street vendor youth in Los Angeles. Journal of Contemporary Ethnography 40: 102-131.

Fairfield, T., and A.E. Charman. 2017. Explicit bayesian analysis for process tracing: Guidelines, opportunities, and caveats. Political Analysis 25: 363-380.

Fernández-Kelly, Patricia, and Jon Shefner, eds. 2006. Out of the shadows: Political action and the informal economy in latin america. University Park: Pennsylvania State University Press.

Hacker, Jacob S. 1998. The historical logic of national health insurance: Structure and sequence in the development of British, Canadian, and U.S. medical policy. Studies in American Political Development 12: $57-130$.

Hall, Peter A., and Rosemary C. Taylor. 1996. Political science and the three new institutionalisms. Political Studies 44: 936-957.

Hansen, Karen, Walter E. Little, and Lynne Milgram, eds. 2013. Street economies in the urban global south. Santa Fe: SAR Press.

Holland, Alisha C. 2015. The distributive politics of enforcement. American Journal of Political Science 59: $357-371$.

Immergut, Ellen M. 1992. The rules of the game: The logic of health policy-making in France, Switzerland, and Sweden. In Structuring politics: Historical institutionalism in comparative analysis, ed. Sven Steinmo, Kathleen Thelen, and Frank Longstreth, 57-89. Cambridge: Cambridge University Press. 
Kalleberg, Arne L., Michael Wallace, and Robert P. Althauser. 1981. Economic segmentation, worker power, and income inequality. American Journal of Sociology 87: 651-683.

Khan, Shamus. 2012. The sociology of elites. Annual Review of Sociology 38: 361-377.

Kirakosyan, Lyusyena. 2013. Linking disability rights and democracy: Insights from Brazil. Societies Without Borders 8: 29-59.

Lamont, Michèle, and Marcel Fournier. 1992. Cultivating differences: Symbolic boundaries and the making of inequality. Chicago: University of Chicago Press.

Lamont, Michèle, and Virág Molnár. 2002. The study of boundaries in the social sciences. Annual Review of Sociology 28: 167-195.

Ledeneva, Alena V. 2006. How Russia really works: The informal practices that shaped post-soviet politics and business. Ithaca: Cornell University Press.

Mahoney, James. 2000. Path dependence in historical sociology. Theory and Society 29: 507-548.

Moraes Silva, Graziella. 2016. After racial democracy: Contemporary puzzles in race relations in Brazil, Latin America and beyond from a boundaries perspective. Current Sociology 64: 794-851.

Município de São Paulo. 1990. Os ambulantes e seu trabalho: Um projeto de institucionalização. São Paulo: Município de São Paulo.

Município de São Paulo. 2002. Diagnósticos e propostas para o desafio do comércio e serviços em vias e lougradouros públicos no centro de São Paulo. São Paulo: Município de São Paulo.

Murphy, Raymond. 1984. The structure of closure: A critique and development of the theories of Weber, Collins, and Parkin. British Journal of Sociology 35: 547-567.

Murphy, Raymond. 1988. Social closure: The theory of monopolization and exclusion. Oxford: Clarendon Press.

North, Douglass C. 1990. Institutions, institutional change and economic performance. Cambridge: Cambridge University Press.

Orrico, Laura A. 2015. Working the boardwalk: Trust in a public marketplace. Social Psychology Quarterly 78 : 228-245.

Pamplona, João Batista. 2013. Mercado de trabalho, informalidade e comércio ambulante em São Paulo. Revista Brasileira de Estudos de Populacão 30: 225-249.

Parkin, Frank. 1974. Strategies of social closure in class formation. In The social analysis of class structure, ed. Frank Parkin, 1-18. London: Tavistock Press.

Pierson, Paul. 2004. Politics in time: History, institutions, and social analysis. Princeton: Princeton University Press.

Ramirez, Henrique, and Pierrette Hondagneu-Sotelo. 2009. Mexican immigrant gardeners: Entrepreneurs or exploited workers? Social Problems 56: 70-88.

Rosales, Rocio. 2014. Stagnant immigrant social networks and cycles of exploitation. Ethnic and Racial Studies 37: 2564-2579.

Roscigno, Vincent J., Sherry Mong, Reginald Byron, and Griff Tester. 2007. Age discrimination, social closure and employment. Social Forces 86: 313-334.

Sørensen, Aage B. 2000. Toward a sounder basis for class analysis. American Journal of Sociology 105: 15231558.

Thelen, Kathleen Ann, and Sven Steinmo. 1992. Historical institutionalism in comparative politics. In Structuring politics: Historical institutionalism in comparative analysis, ed. Sven Steinmo, Kathleen Thelen, and Frank Longstreth, 1-32. Cambridge: Cambridge University Press.

Tilly, Charles. 1998. Durable inequality. Berkeley: University of California Press.

Waldinger, Roger D. 1997. Social capital or social closure? Immigrant networks in the labor market. Working Paper. The Ralph and Goldy Lewis Center for Regional Policy Studies Working Paper Series. https://escholarship.org/uc/item/06z6331r. Accessed 15 Dec 2018.

Weber, Max. 1978. Economy and society: An outline of interpretive sociology. Berkley: University of California Press.

Weeden, Kim A. 2002. Why do some occupations pay more than others? Social closure and earnings inequality in the United States. American Journal of Sociology 108: 55-101.

Weeden, Kim A., and David B. Grusky. 2005. The case for a new class map. American Journal of Sociology 111: 141-212.

Wright, Erik O. 1997. Class counts: Comparative studies in class analysis. Cambridge: Cambridge University Press.

Jacinto Cuvi received a master's degree from Sciences Po and a Ph.D. in sociology from the University of Texas at Austin. He is currently a postdoc at the University of Neuchâtel in Switzerland. 